\title{
INTERSPECIES AND GENDER-RELATED VARIATIONS OF SOME HAEMATOLOGICAL PARAMETERS IN GALLIFORMES BIRD SPECIES
}

\author{
L. LASHEV ${ }^{1}$, S. ATANASOVA ${ }^{2} \&$ T. DINEV ${ }^{1}$ \\ ${ }^{1}$ Department of Pharmacology, Physiology and Physiological Chemistry, \\ Faculty of Veterinary Medicine, Trakia University, Stara Zagora, Bulgaria; \\ ${ }^{2}$ Department of Biochemistry, Microbiology and Physics, Faculty of Agricul- \\ ture, Trakia University, Stara Zagora, Bulgaria
}

\section{Summary}

Lashev, L., S. Atanasova \& T. Dinev, 2015. Interspecies and gender-related variations of some haematological parameters in Galliformes bird species. Bulg. J. Vet. Med., 18, No. 4, $325-337$.

\begin{abstract}
An analysis of literature data about routine haematological parameters of avian species from the Galliformes order is made. Data for the following gallinaceous birds were included: wild and domesticated chicken breeds, common pheasant, quail, turkey, peafowl and guinea fowl. Data for red and white blood picture indices such as haemoglobin, red blood cells (RBC), packed cell volume (PCV), total and differential white blood cell (WBC) counts from the literature as well as own data were used. Gender-related differences were reported by most of authors for RBC, haemoglobin and PCV with higher values in male birds from the Gallus gallus species. Similar results were not found in other species of the order. In most of the cases no statistically significant interspecies or gender-related differences in WBC counts were registered. Tendencies for higher heterophil/lymphocyte ratios (H/L) in male birds were also registered. Differences related to the breed, result of various degree of domestication, were not identified.
\end{abstract}

Key words: birds, gallinaceous, haematology, interspecies and sex related differences

\section{INTRODUCTION}

The rearing of wild or domesticated bird species from the Galliformes order has been of considerable economical importance at all stages of the humankind development. The existing species and breeds provide information for the entire process of domestication that is especially clear for Gallus gallus. There are numerous studies and data about the condition of birds (especially domesticated species) and the factors influencing it. Haematological investigations are among the most widely used and easily available. The existing information about the different gallinaceous species varies considerably. The most numerous and detailed studies 
are about domesticated species - chickens, turkeys etc., whereas data about wild ones, including game species reared in aviaries, are rather limited (Mihailov et al., 1999; Lashev et al., 2007; Strakova et al., 2010). The present research reports differences related to the species, age, season and gender in Gallus gallus, Meleagris gallopavo, Phasianus colchicus, Coturnix coturnix and others. So far, there are no studies summarising the data about gender-related differences in blood indices of species from the Galliformes order.

The purpose of the present paper was to analyse interspecies and gender-related differences in principal haematological parameters of gallinaceous birds on the basis of literature data and own results. We have also attempted to evaluate the influence of environmental factors as a result of domestication level and urbanisation on the most commonly analysed blood parameters of the Gallus gallus spp. using data for various breeds of this species.

\section{MATERIALS AND METHODS}

Data from haematological investigations of healthy representatives of both genders of gallinaceous bird species, published by various authors, were used. The references included in the analysis are cited in Tables 1 and 2. The following blood parameters were included in the analysis: red blood cells (RBC), haemoglobin $(\mathrm{Hb})$, packed cell volume (PCV), total white blood cells (WBC) counts, differential WBC counts, heterophil/lymphocyte ratio $(\mathrm{H} / \mathrm{L})$. All blood analyses were standardised, allowing an unbiased comparison. The data are presented as they appeared in original publications, and in some instances were converted in uniform units for compara- tive purposes. Principal Component Analysis (PCA) was used for identifying patterns in data expressing them in a way such as to highlight their similarities and differences. A commercial software Pirouette Version 3.02 (Infometrics, Inc., Woodinville, WA, USA) was used.

\section{RESULTS}

The data for the haematological parameters showed variations among species and among different reports. With regard to RBC counts, haemoglobin content and PCV, different sources reported higher values in male birds with statistically significant differences mainly in wild and domestic chickens (Table 1). These tendencies did not exist in other analysed gallinaceous species. In an inter-species aspect quails and pheasants exhibited relatively higher values of red blood picture parameters as compared to other species included in the analysis. The chickens reared at unusually high altitudes as Kashmir favorella did not have higher levels of $\mathrm{Hb}$ or $\mathrm{RBC}$ count. The WBC counts were highly variable both within and among species. In most instances, female birds had higher lymphocyte and lower heterophil percentages (Table 2). Included birds demonstrated considerable variations of the $\mathrm{H} / \mathrm{L}$ ratio which, in most instances, was higher in male birds. The absolute values and percentages of monocytes, eosinophils and basophils showed considerable intra- and inter-species variations in chickens, pheasants and quails, but were similar when both sexes of one species were compared. Extremely high monocyte counts were reported for Kashmir favorella. At a lesser extent, this was true for eosinophils. 
Table 1. Values of selected red blood indices in species from the Galliformes order

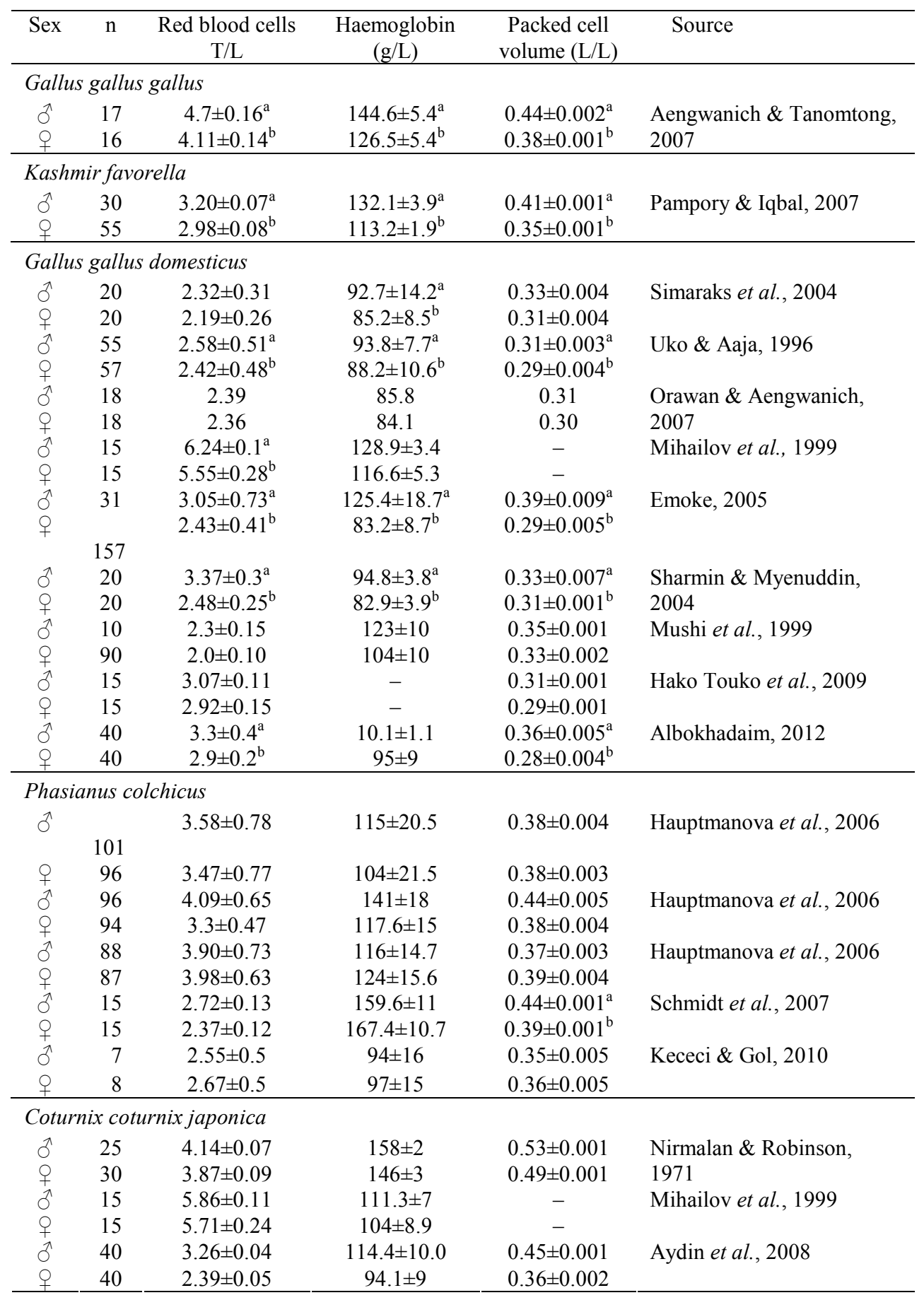


Interspecies and gender-related variations of some haematological parameters in Galliformes ....

Table 1 (cont'd). Values of selected red blood indices in species from the Galliformes order

\begin{tabular}{|c|c|c|c|c|c|}
\hline Sex & $\mathrm{n}$ & $\begin{array}{c}\text { Red blood cells } \\
\text { T/L } \\
\end{array}$ & $\begin{array}{c}\text { Haemoglobin } \\
(\mathrm{g} / \mathrm{L})\end{array}$ & $\begin{array}{c}\text { Packed cell } \\
\text { volume }(\mathrm{L} / \mathrm{L})\end{array}$ & Source \\
\hline$\hat{0}$ & & $2.63 \pm 0.10$ & $110.5 \pm 60$ & $0.33 \pm 0.002$ & Farahat et al., 2010 \\
\hline 우 & & $2.84 \pm 0.13$ & $117.1 \pm 5.2$ & $0.34 \pm 0.001$ & \\
\hline \multicolumn{6}{|c|}{ Meleagris gallopavo } \\
\hline o & 13 & $1.30 \pm 0.2$ & $167 \pm 1.8$ & $0.39 \pm 0.005$ & Schmidt et al., 2009 \\
\hline q & 40 & $1.13 \pm 0.23$ & $162 \pm 20$ & $0.37 \pm 0.005$ & \\
\hline$\lambda$ & 22 & $0.96 \pm 0.27$ & $172 \pm 17$ & $0.36 \pm 0.003$ & Schmidt et al., 2009 \\
\hline o & 35 & $1.05 \pm 0.27$ & $176 \pm 19$ & $0.37 \pm 0.004$ & \\
\hline$\hat{0}$ & 10 & $1.99 \pm 0.38$ & $137.9 \pm 26.6$ & $0.40 \pm 0.004$ & Azeez et al., 2011 \\
\hline q & 10 & $2.26 \pm 0.28$ & $130.9 \pm 22.2$ & $0.40 \pm 0.004$ & \\
\hline$\hat{\sigma}$ & 15 & $2.42 \pm 0.2$ & $112.2 \pm 6$ & $0.42 \pm 0.002$ & Lazar et al., 2012 \\
\hline 오 & 15 & $2.82 \pm 0.9$ & $100.7 \pm 9$ & $0.43 \pm 0.001$ & \\
\hline \multicolumn{6}{|c|}{ Meleagris ocelata } \\
\hline$\sigma^{\pi}$ & 2 & $2.35 \pm 1.24$ & $134.5 \pm 32.4$ & $0.40 \pm 0.008$ & Ortiz, 2004 \\
\hline 오 & 9 & $2.37 \pm 0.28$ & $134.3 \pm 8$ & $0.40 \pm 0.008$ & \\
\hline \multicolumn{6}{|c|}{ Numida meleagris } \\
\hline o & 41 & $3.45 \pm 0.62$ & $106.8 \pm 11.6$ & $0.36 \pm 0.001$ & Uko \& Ataja, 1996 \\
\hline o & 37 & $3.40 \pm 0.64$ & $105.1 \pm 10.4$ & $0.33 \pm 0.006$ & \\
\hline$\hat{a}$ & 49 & $2.65 \pm 0.09$ & $142 \pm 5.4$ & $0.41 \pm 0.007$ & Nalubamba et al., 2010 \\
\hline 우 & 40 & $2.44 \pm 0.1$ & $124 \pm 2.9$ & $0.38 \pm 0.005$ & \\
\hline \multicolumn{6}{|c|}{ Pavo cristatus } \\
\hline$\hat{0}$ & 17 & $3.54 \pm 0.3$ & $115.1 \pm 15$ & - & Lashev et al., 2013 \\
\hline 우 & 19 & $3.42 \pm 0.4$ & $101.2 \pm 12$ & - & \\
\hline
\end{tabular}

RBC- red blood cells, PCV-packed cell volume, $n$ - number of birds; ${ }^{a}$ b means in the same column with different letters are significantly different $(\mathrm{P}<0.05)$.

The Principal Component Analysis was applied separately for RBC and WBC data. When data for $\mathrm{RBC}$ were transformed into Principal Components, the first principal component (RBC values) explained $87.6 \%$ of total variations in the data, the second principal component (haemoglobin values) explained 11.2\% and the third personal component (PCV values) $-1.2 \%$ respectively. Principal component 1 correlated mainly with the variable PCV $(\mathrm{r}=0.946)$, the second: with haemoglobin $(\mathrm{r}=0.928)$, and the third with $\mathrm{RBC}(\mathrm{r}=0.976)$.

The distribution of tested species in the space of the first two principal components is presented on Fig. 1. Quails formed a relatively separate group. Points corresponding to other species did not form a separate group.

The results of principal component analysis, applied for WBC data are presented in Table 3. Distribution of tested species in the space of principal component 1 (WBC count) and principal component 2 (lymphocytes) is presented on Fig. 2. No bird species was found to form a separate group.

\section{DISCUSSION}

The results included in the present analysis were obtained by different researchers, in different laboratories, latitudes and cli- 


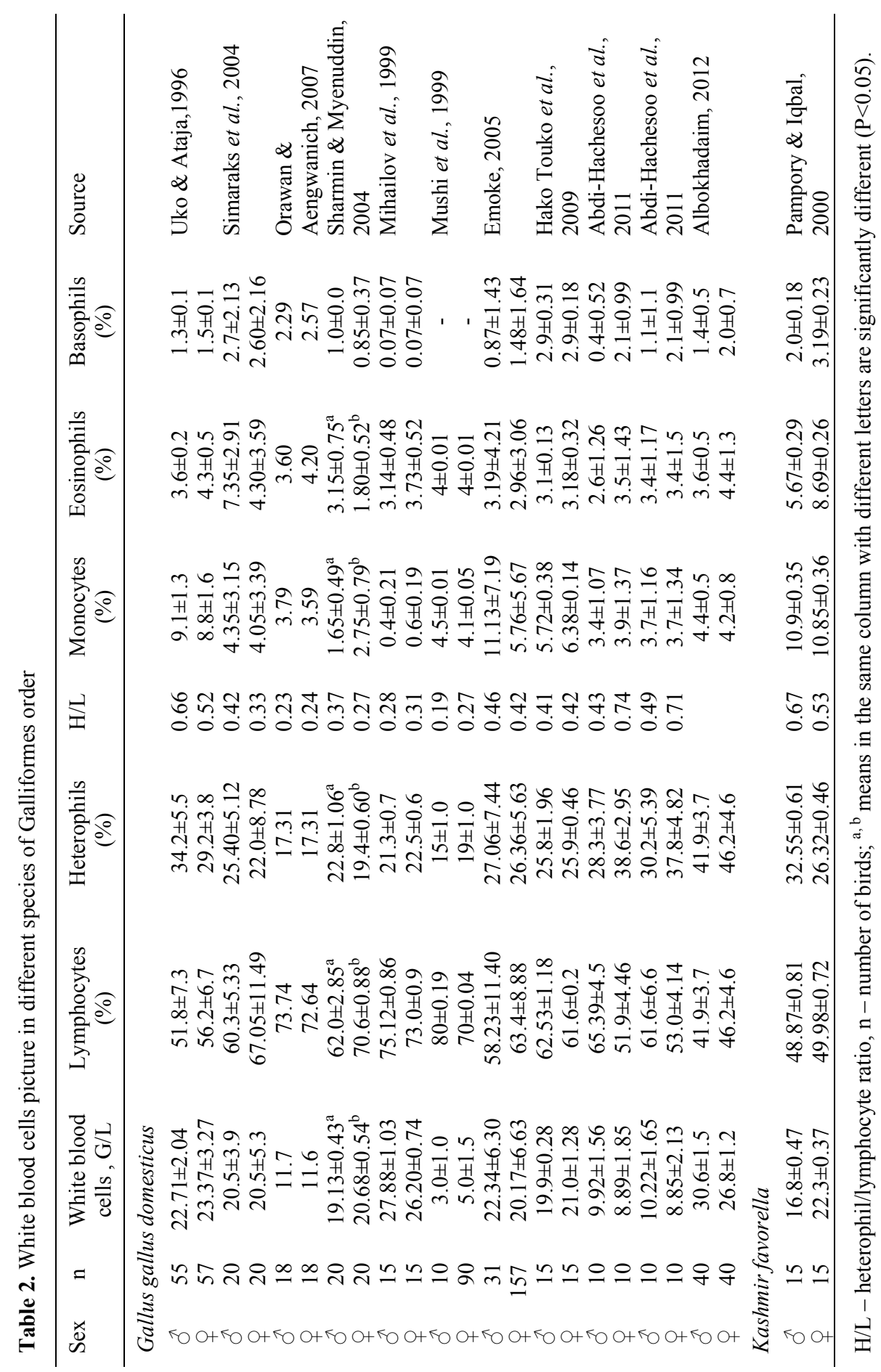


Interspecies and gender-related variations of some haematological parameters in Galliformes ....

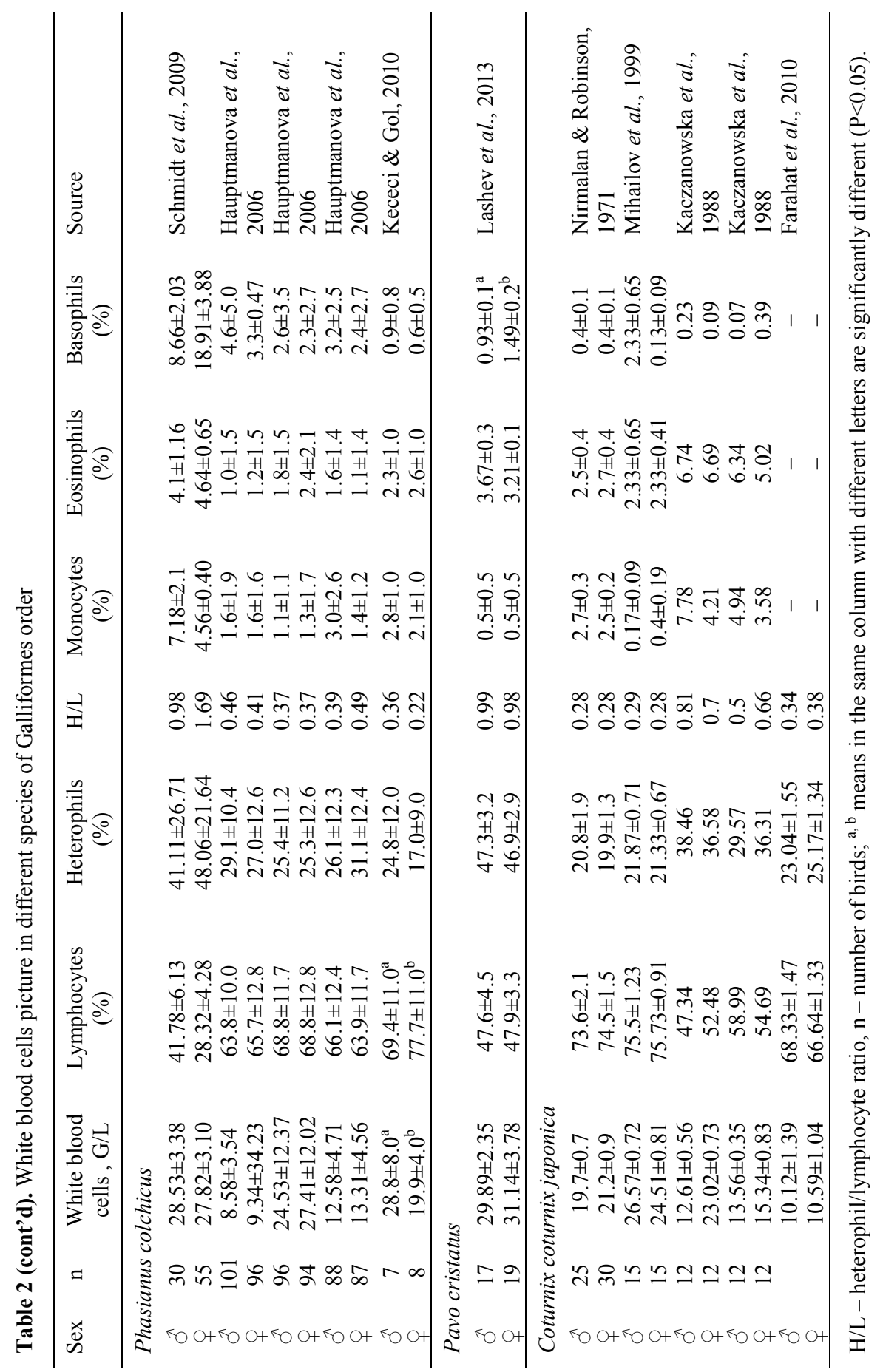




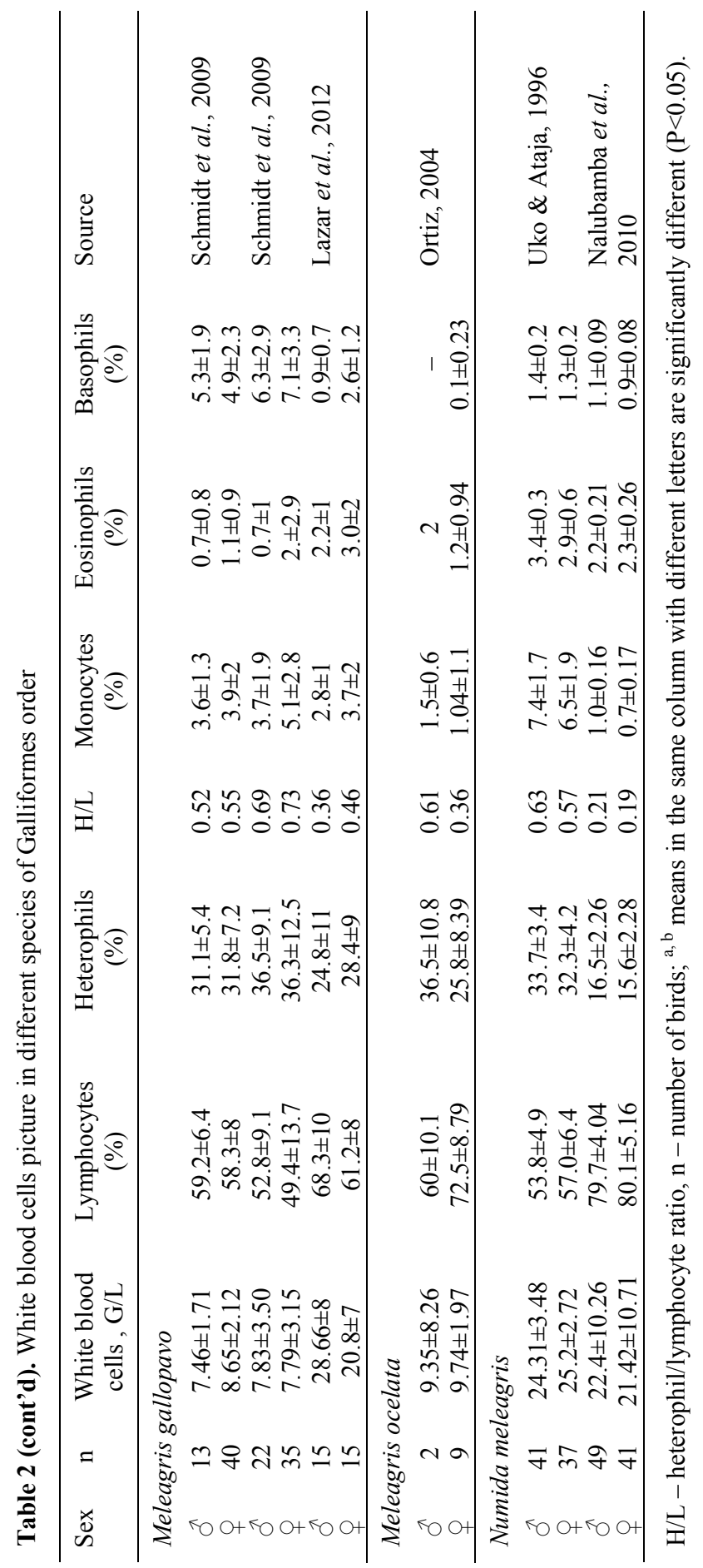


Interspecies and gender-related variations of some haematological parameters in Galliformes ....

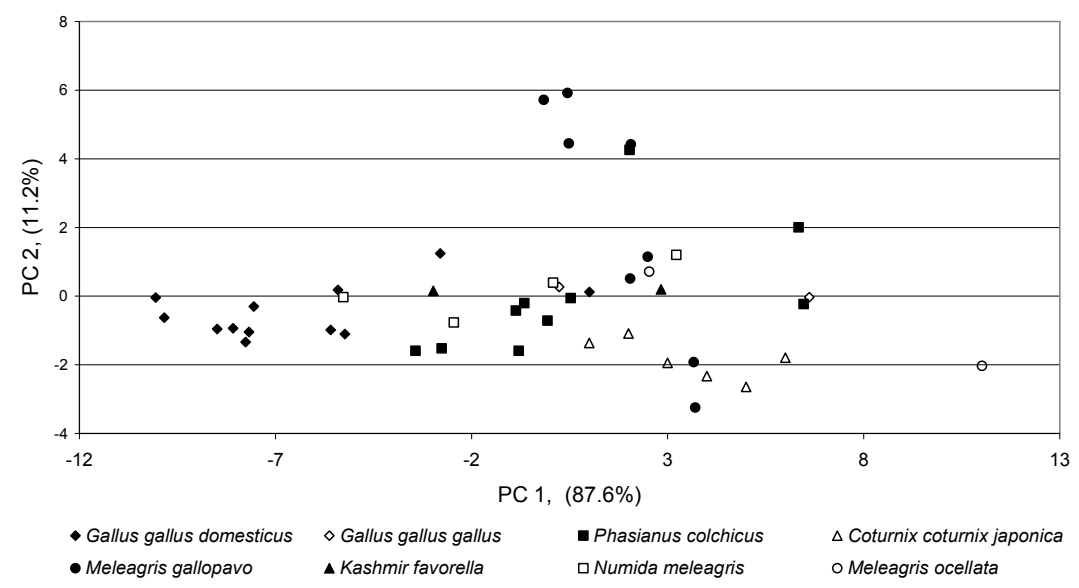

Fig. 1. Score plot of principal component (PC) 1 (red blood cells) and PC 2 (haemoglobin), calculated from red blood cell data.

Table 3. Results from principal component analysis, applied for white blood cell (WBC) data

\begin{tabular}{lcl}
\hline Factors & Percent of total variance & Highest correlation with \\
\hline Principal component 1 (WBC count) & 71.31 & Lymphocytes \\
Principal component 2 (lymphocytes) & 19.67 & White blood cells \\
Principal component 3 (heterophils) & 5.23 & Heterophils \\
Principal component 4 (monocytes) & 2.84 & Basophils \\
Principal component 5 (eosinophils) & 0.72 & Eosinophils, monocytes \\
Principal component 6 (basophils) & 0.23 & Eosinophils \\
\hline
\end{tabular}

mate conditions. These differences could have a significant impact upon studied parameters and be responsible for the large amount of inter- and intra-species variations registered. Therefore, sex-related differences could be accepted as more precisely evaluated whereas breed-related (including those connected with domestication) or species-related could be outlined only as a trend. It was difficult to recognise the individual influence of any specific factor as well.

The data for a particular species were not uniform with regard to their quantity and possibilities for analysis. They are the most abundant for chickens and thus, provide substantial evidence in support of conclusions made, particularly with respect to gender-related differences in red blood picture parameters. It should be emphasised that such differences were reported by investigators for various latitudes, altitudes and breeds. It could be assumed that they could be valid for the other gallinaceous bird species with less data available, because in these studies the general trend was also confirmed. 


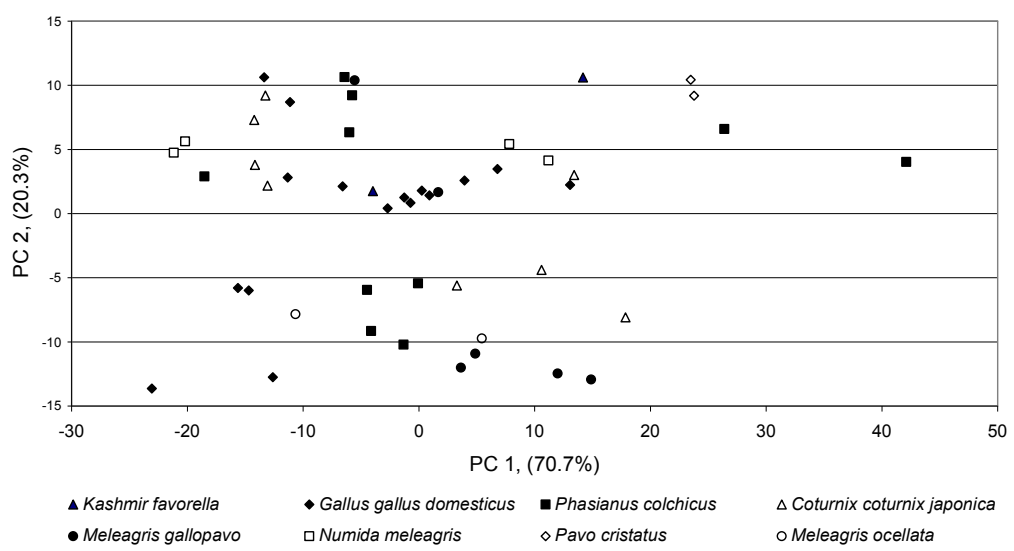

Fig. 2. Score plot of principal component (PC) 1 (white blood cells) and PC2 (lymphocytes), calculated from WBC data.

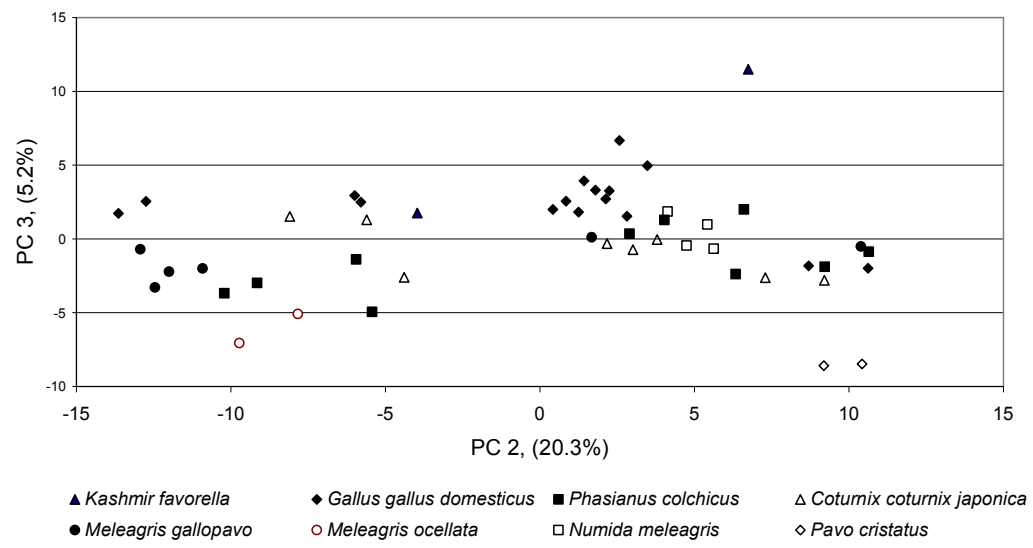

Fig. 3. Score plot of principal component (PC) 2 (lymphocytes) and PC3 (heterophils), calculated from WBC data.

According to the data, roosters often show higher values of RBC, PCV and haemoglobin. A possible reason for the difference is the higher level of oestrogens in blood of female birds, which depresses erythropoiesis, whereas androgens have the opposite action (Herbert et al., 1989; Itoh, 1992). Another factor could be the considerably decreased haemoglobin level associated to the intensity of egg production (Uko \& Ataja, 1996). Only female pheasants and bronze turkeys have higher values of previously mentioned indices than males of the same species (Hauptmanova et al., 2006; Schmidt et al., 2007). These findings could be due to other factors such as environment, age, reproduc- 
tive status and season (Herbert et al., 1989; Hauptmanova et al., 2006).

With regard to intra-species variations, it could be concluded that indigenous breeds of domesticated chickens living freely in conditions similar to those of their wild relatives, exhibited lower RBC counts than urbanised intensively reared breeds. Data could reflect better conditions of rearing and the complete and balanced ration (Herbert et al., 1989).

The high values of PCV in Japanese quails might be attributed to genetic factors. Moreover, slight increases in the peripheral red blood cells mass may occur in excited or stressed avian patients (Fudge, 2000). The high values of PCV in wild non-gallinaceous birds also support that statement (Okeudo et al., 2003; Aengwanich \& Tanomtong, 2004; Milani, 2009).

There is a considerable variability in the total WBC counts not only between species of the Galliformes order, but also between different breeds within the same species. Total and differential WBC counts can provide valuable information about the state of the immune system and whether birds have been exposed to infectious or immunotoxic agents (Campbell \& Coles, 1986). A high WBC counts in birds with high extent of domestication should be noted (Mihailov et al., 1999; Yarkov, 2001). The analysis often showed higher WBC counts in females although this tendency was not always present (Table 2). Also, substantial differences in $\mathrm{H} / \mathrm{L}$ ratios among species and breeds were found. The H/L ratio reflects the various rearing conditions of birds, subject of analysed studies. In most cases males have higher $\mathrm{H} / \mathrm{L}$ values (also non-gallinaceous birds), as reported by Fairbrother \& O'Loughlin (1990); Plischke et al. (2009), although some authors found the opposite tendency (Mihailov et al., 1999). The breed of the examined birds in the last study was White Plymouth Rock. It is widely known that under stress conditions the number of heterophils increases and the number of lymphocytes is reduced (Davis et al., 2008). The higher $\mathrm{H} / \mathrm{L}$ ratios in females in this study may result from stress due to the laying cycle (Latimer \& Bienzle, 2000). This effect is also observed in tundra swans, ostriches and lesser adjutants (Levi et al., 1989; Salakij et al., 2004; Milani, 2009). Their high $\mathrm{H} / \mathrm{L}$ values could be at least partly due to the stress, involving handling of the wild animals (Davis et al., 2008).

In conclusion, it could be said that Gallus gallus gallus showed sex-related differences in the number of RBC, as well as in haemoglobin content and PCV. The influences of the climate, breed or technology are not sufficient for significant changes of the red and white blood picture indices. According to the principal component analysis, the biggest variations among species existed in the PCV values, followed by haemoglobin values and RBC counts. The results of principal component analysis, applied for WBC data of tested species in the space of PC2 and PC3 shows that only the Meleagris gallopavo and Pavo cristatus species formed separate groups. The other bird species were not separated because of the smaller variations in RBC. Our data allowed supporting partly the conclusions of Scanes \& Christensen (2014) concerning the differences between blood parameters of wild and domesticated species belonging to Galliformes order.

\section{REFERENCES}

Abdi-Hachesoo, B., A. Talebi \& S. AsriRezaei, 2011. Comparative study on blood profiles of indigenous and Ross-308 broi- 
ler breeders. Global Veterinaria, 7, 238 241.

Aengwanich, W. \& A. Tanomtong, 2004. Hematological and serum biochemistry values of white ibis (Threskiornis melanocephalus). Songklanakarin Journal of Science and Technology, 26, 823-828.

Aengwanich, W. \& A. Tanomtong, 2007. Blood cell characteristics and hematological values of free ranging-red jungle fowl (Gallus gallus) in northeastern Thailand. Journal of Biological Science, 7, 689-692.

Albokhadaim, I., 2012. Hematological and some biochemical values of indigenous chickens in Al-Ahsa, Saudi Arabia during summer season. Asian Journal of Poultry Science, 6, 138-145.

Aydin, C., M. Petek \& R. Cibik, 2008. Effect of recessive colour mutation on haematological characteristics of Japanese quails. (Coturnix coturnix japonica). Archiv für Geflugelkunde, 72, 164-167.

Azeez, O., F. Olayemi \& J. Olanrewaju, 2011. Age and sex influence on the haematology and erythrocyte osmotic fragility of the Nigerian turkey. Research Journal of Veterinary Science, 4, 43-49.

Campbell, T. \& E. Coles, 1986. Avian clinical pathology. In: Veterinary Clinical Pathol$o g y$, ed E. H. Coles, WB Saunders, Philadelphia, USA, pp. 279-301.

Davis, A. K., D. L. Maney \& J. K. Maerz, 2008. The use of leucocyte profiles to measure stress in vertebrates: a review for ecologists. Functional Ecology, 22, 760772.

Emoke, V., 2005. Hematological values of the native yellow Hungarian breed. PhD Thesis, Mosonmagyarovar, Hungary.

Fairbrother, A. \& D. O'Loughlin, 1990. Differential white blood cell values of the mallard (Anas platyrhynchos) across different ages and reproductive states. Journal of Wildlife Diseases, 26, 78-82.

Farahat, G. S., N. M. El-Bahy \& O. Y. Mahfoz, 2010. Genetic parameter estimates for glutation peroxydase and some blood constituents and their association with some growth traits in Japanese quail. Egyptian Poultry Science, 30, 847-873.

Fudge, A., 2000. Laboratory Medicine Avian and Exotic Pets, WB Saunders, Philadelphia, p. 486.

Hako Touko, B.A., Y. Manjeli, J. AwahNdukum \& T. C. Keambou, 2009. Effect of genetic group and sex on haematological parameters and the viability of the local fowl (Gallus domesticus) in Cameroon. Livestock Research for Rural Development, 21, 1-6.

Hauptmanova, K., M. Maly \& I. Literak, 2006. Changes of haematological parameters in common pheasant throughout the year. Veterinarni Medicina, 51, 29-34.

Herbert, R., J. Nanney \& J. S. Spano, 1989. Erythrocyte distribution in ducks. American Journal of Veterinary Research, 50, 958-960.

Itoh, N., 1992. Some hematological values in budgerigars. Journal of Rakuno Gakuen University, 17, 61-64.

Kaczanowska, E., K. Gromysz-Kalkowska \& E. Szubartowska, 1988. Morphotic composition of bone marrow and peripheral blood in various periods of the life cycle of the Pharaoh quail (Coturnix coturnix Pharaoh) III. Peripheral blood-white blood cell system. Folia Biologica, 1-2, 19-28.

Kececi, T. \& R. Gol, 2010. Haematological and biochemical values of the blood of pheasant (Phasianus colchicus) of different ages. Turkish Journal of Veterinary and Animal Science, 34, 1-7.

Lashev, L., R. Mihailov, I. Matev, V. Lasheva, A. Haritova \& U. Daskalov, 2007. Comparison of some values of the blood indices of birds from families Phasianidae and Meleagrididae, order Galliformes. Veterinarna Sbirka, 115, 16-19 (BG).

Lashev, L., R. Mihailov \& V. Lasheva, 2013. Hematological profile of peacocks reared in Bulgaria. In: Proceedings of the International Scientific Conference "90 Years 
Interspecies and gender-related variations of some haematological parameters in Galliformes ....

Faculty of Veterinary Medicine in Bulgaria”, Stara Zagora, 30-31 May. p. 24.

Latimer, K. S. \& D. Bienzle, 2000. Determination and interpretation of the avian leukogram. In: Schalm's Veterinary Hematol$o g y$, eds B. F. Feldman, J. G. Zinkl \& N. C. Jain, Lippincott Williams and Wilkins. Philadelphia, pp. 417-432.

Lazar, R., P. C. Boisteanu, C. Muntean, C.-A. Apetroaei \& M. M. Ciobanu, 2012. Characterisation of the haematologocal profile of the hybrid B.U.T 6 Tureky raised in Romania. University of Agricultural Sciences and Veterinary Medicine Iasi - Seria Zootehnie, 58, 254-257.

Levi, A., B. Perelman, T. Waner, M. M. van Grevenbroek, C. van Creveld \& R. Yagil, 1989. Haematological parameters of the ostrich (Struthio camelus). Avian Pathology, 18, 321-327.

Mihailov, R., V. Lasheva \& L. Lashev, 1999. Some hematological values in Japanese quails. Bulgarian Journal of Veterinary Medicine, 2, 137-139.

Milani, J. F., 2009. Hematology and plasma chemistry reference values, body mass scores, and fecal bacteriological analysis in tundra swans, Cygnus columbianus. MPVM Thesis, School of Veterinary Medicine, University of California, Davis, USA.

Mushi, E. Z., M. G. Binta, R. G. Chabo \& R. T. Ndebele, 1999. Haematological studies on apparently healthy Tswana indigenous chickens (Gallus domesticus) around Gaborone, Botswana. INFPD Newsletter, 9, 3-8.

Nalubamba, K. S., N. B. Mudenda \& M. Masuki, 2010. Indices of health; clinical haematology and body weight of freerange guinea fowl (Numida meleagris) from the southern province of Zambia. International Journal of Poultry Science, 9 , 1083-1086.

Nirmalan, G. P. \& G. A. Robinson, 1971, Haematology of the Japanese quail ( $\mathrm{Co}$ turnix coturnix japonica). British Poultry Science, 12, 475-481.
Okeudo, N. J., Okoli, I. C. \& G. O. F. Igwe, 2003. Hematological characteristics of ducks (Cairina moschata) of Southeastern Nigeria. Tropicultura, 21, 61-65.

Orawan, C. \& W. Aengwanich, 2007. Blood cell characteristics, hematological values and average daily gained weight of Thai indigenous crossbred and broiler chickens. Pakistan Journal of Biological Science, 10, 302-309.

Ortiz, J. M. U., 2004. Determination de valores de referential para hematologia, quimica y morfometria del Pavo ocelado (Meleagris ocellata) en el perque nacional tikal, peten, Guatemala: efectos del sexo. $\mathrm{PhD}$ Thesis, Universidad de san Carlos de Guatemala.

Pampori, Z. \& S. Iqbal, 2007. Haematology, serum chemistry and electrocardiographic evaluation in native chicken of Kashmir International Journal of Poultry Science. 6, 578-582.

Plischke, A., P. Quillfeldt, T. Lubjuhn, S. Merino \& J. F. Masello, 2009. Leucocytes in adult burrowing parrots Cyanoliseus patagonus in the wild: Variation between contrasting breeding seasons, gender, and individual condition. Journal of Ornithology, 151, 347-354.

Salakij, C., J. Salakij, N. Rochanapat \& D. Pitakkingthong, 2004. Hematology, morphology and cytochemistry of blood cells in lesser adjutant (Leptoptilos javanicus) and greater adjutant (Leptoptilos dubius). Kasetsart Journal, 38, 400-408.

Scanes, C. \& K. Christensen, 2014. Comparison of meta-analysis of the hematological parameters of commercial and indigenous poultry to wild birds: implications to domestication and development of commercial breeds/lines. Journal of Veterinary Science and Animal Health, 1, 1-12.

Schmidt, E. M. S., A. C. Paulillo, E. Santin, R. L. Dittrich \& E. G. de Oliveira, 2007. Hematological and serum chemistry values for the ring-necked pheasant (Phasianus colchicus): Variation with sex and age. In- 
ternational Journal of Poultry Science, 6 , 137-139.

Schmidt, E. M. S., A. C. Paulillo, G. R. V. Martins, I. M. Lapera, A. J. P. Testi, L. N. Junior, J. Denadai \& J. J. Fagliari, 2009. Hematology of the bronze turkey (Meleagris gallopavo): Variations with age and gender. International Journal of Poultry Science, 8, 752-754.

Sharmin, M. L. \& M. Myenuddin, 2004. Hematological values of the indigenous chickens. Bangladesh Journal of Veterinary Medicine, 2, 163-164.

Simaraks, S., O. Chinrasri \& W. Aengwanich, 2004. Hematological, electrolyte and serum biochemical values of the Thai indigenous chickens (Gallus domesticus) in northeastern Thailand. Songklanakarin Journal of Science and Technology, 26, 425-430.

Strakova, E., P. Suchy, R. Kabelova, F. Vitula \& I. Herzig, 2010. Values of selected haematological indicators in six species of feathered game. Acta Veterinaria Brno, 79, Suppl. 9, 3-8.

Uko, O. J. \& A. M. Ataja, 1996. Haematological studies of pure indigenous domestic fowl (Galus domesticus) and guinea fowl (Numida meleagris) in north-west Nigeria.
Revue d'Elevage et Médecine Vétérinaire des Pays Tropicaux, 49, 257-262.

Yarkov, D. J., 2001. Influence of Vaztak 10 EK insecticide in White Plymouth Rock chickens and White Cornish chickens with different Akp genotype. PhD Thesis, Stara Zagora, Bulgaria

Paper received 04.09.2013; accepted for publication 25.04.2014

\section{Correspondence:}

Dr. Lubomir D. Lashev, Professor Department of Pharmacology, Physiology and Physiological Chemistry, Faculty of Veterinary Medicine, Trakia University, Student Campus, 6000 Stara Zagora, Bulgaria, tel. +359888001850 ,

e-mail: lashev@uni-sz.bg 